\title{
Near-surface ventilation as a key for modeling the thermal regime of coarse blocky rock glaciers
}

\author{
Luisa Pruessner ${ }^{1,2}$ (D) | Marcia Phillips ${ }^{3}$ | Daniel Farinotti ${ }^{1,2}$ | Martin Hoelzle ${ }^{4}$ | \\ Michael Lehning ${ }^{3,5}$
}

\author{
${ }^{1}$ Laboratory of Hydraulics, Hydrology and \\ Glaciology (VAW), ETH Zürich, Zürich, \\ Switzerland \\ ${ }^{2}$ Swiss Federal Institute for Forest, \\ Birmensdorf, Switzerland \\ ${ }^{3}$ WSL Institute for Snow and Avalanche \\ Research, Davos, Switzerland \\ ${ }^{4}$ Alpine Cryosphere and Geomorphology, \\ Department of Geosciences, University of \\ Fribourg, Fribourg, Switzerland \\ ${ }^{5}$ Laboratory of Cryospheric Sciences CRYOS, \\ School of Architecture, Civil and \\ Environmental Engineering, Ecole \\ Polytechnique Fédérale de Lausanne (EPFL), \\ Lausanne, Switzerland \\ Correspondence \\ Luisa Pruessner, Laboratory of Hydraulics, \\ Hydrology and Glaciology (VAW), ETH Zürich, \\ Hönggerbergring 26, 8093 Zürich, \\ Switzerland. \\ Email: pruessner@vaw.baug.ethz.ch
}

\begin{abstract}
In a changing climate, ice-rich permafrost features such as rock glaciers will experience drastic changes. Modeling the heat transport through the blocky surface layer with its large interstitial pore spaces poses some challenges as various modes of non-conductive heat transport-advective forms in particular-can occur. Here, we show that the 1D physics-based model SNOWPACK can be used with a suitably adapted parameterization of ventilation to represent heat transport with reasonable accuracy. To do so, only one site-specific parameter, which is linked to the size of the pores in the blocky layer, is used. Inclusion of this ventilation parameterization is shown to be important for modeling the thermal regime at three experimental sites in the Swiss Alps. Furthermore, it could be shown that (i) snow depth dynamics exert a strong control on the thermal regime, (ii) the ice-content stratigraphy needs to be known precisely and (iii) the augmented heat flux through the blocky layer caused by ventilation in both snow and blocks is important.
\end{abstract}

KEYWORDS

active layer, rock glacier, snowpack, thermal regime, ventilation

\section{1 | INTRODUCTION}

With an ever evolving climate, mountain permafrost is undergoing thermal changes. While glaciers are retreating fast (estimates suggest that up to half the global glacial volume could be lost by the end of the century ${ }^{1}$ ), rock glaciers are thought to be less sensitive to climate change. ${ }^{2}$ The coarse rock layers, characteristic of rock glaciers, have been found to allow permafrost to exist where the mean annual air temperature is above $0^{\circ} \mathrm{C}$ in mountainous regions. ${ }^{3}$ Rock glaciers occur in the periglacial belt in nearly all high mountain systems of the world. ${ }^{4}$ As runoff from glaciers is projected to decrease in the long term ${ }^{5}$ rock glaciers may gain in importance as a potential water source in regions that rely heavily on glacial runoff, such as Central Asia. ${ }^{6}$ To make projections about the potential future water availability and the fate of rock glaciers themselves it is necessary to be able to model the thermal regime of rock glaciers reliably.

The difficulty in modeling the thermal regime of rock glaciers lies mostly with the blocky surface layer, ie, the uppermost layer consisting of rocks, often large, and boulders. Apart from the rough, heterogeneous surface which complicates the surface energy balance, ${ }^{7-10}$ large blocks with large pore spaces allow not only for conductive and diffusive processes but also for advective modes of heat transport. When considering natural convection, the movement of air due to buoyancy forces, a distinction can be made between open pores and closed pores. Open pores allow for the chimney effect, while closed pores allow for RayleighBénard convection. The chimney effect describes a process by which warm air is replaced by cold air through advective transport through open pore spaces in the blocky layer. ${ }^{11,12}$ This type of convection has been shown to have a significant cooling effect on the thermal regime of rock glaciers. ${ }^{13,14}$ Rayleigh-Bénard convection describes the process by which a temperature difference between floor and ceiling of a closed pore space creates convective motion. This process can be extended to pore spaces filled with porous media in which case it is known as the Horton-RogersLapwood problem, ${ }^{15}$ which has been shown to have a cooling effect in blocky layers. ${ }^{3}$ However, the exact processes cannot be modeled explicitly in a 1D model but need to be parameterized. 
Here, the SNOWPACK model ${ }^{16,17}$ is used to model the rock glacier's thermal regime. This $1 \mathrm{D}$ physics-based model contains a ventilation module,${ }^{17}$ which is intended to provide a parameterization of the vertical component of processes of forced convection or wind-induced airflow. ${ }^{18}$ In ice-rich layers, by contrast, conductive heat transfer dominates (in the absence of cracks or shafts in the ice), which is included in the model in the form of the conduction-diffusion equation. The model also incorporates a soil module (cf. Methods), which allows its use to be extended to the subsurface ground domain (here the rock glacier). Model forcing is supplied in the form of the following meteorological variables: at least one shortwave radiation component, air temperature, incoming long-wave radiation or (in case of a nonphase-changing surface) surface temperature, wind speed and direction, humidity, and snow height.

For long-term studies the thermal regime of the icy layer is of most interest to determine any potential discharge from rock glaciers. However, this requires knowledge of the heat transport through the blocky layer. The focus of this study is then to model the heat transport, determined by the meteorological forcing supplied to the model, through the blocky layer to the icy layer. The model domain is thus chosen to include the entire thickness of the blocky layer and part of the underlying icy layer. Including the icy layer is important to ensure that the heat transport through the blocky layer is simulated correctly because this will determine the temperatures in the icy layer.
This paper investigates three ice-rich rock glaciers at study sites in the Swiss Alps (Murtèl-Corvatsch, Ritigraben and Schafberg; see Figure 1, and next section) for which extensive borehole temperature and meteorological forcing data are available. The sites are simulated using the SNOWPACK model with and without the ventilation module. Additional runs were performed showing the effect of reduced ice content in the icy layer (Murtèl) and the effect of snow height (Ritigraben).

\section{2 | SITE DESCRIPTIONS}

\section{1 | Murtèl}

The Murtèl-Corvatsch rock glacier is one of the most studied permafrost features and has the longest data series in mountain permafrost worldwide., ${ }^{7,19-24}$ It is located in the Upper Engadine in the Swiss Alps at an elevation of $2670 \mathrm{~m}$ a.s.l. and with a mean slope of $10^{\circ}$. It is about $400 \mathrm{~m}$ long and $200 \mathrm{~m}$ wide (total area of $0.08 \mathrm{~km}^{2}$ as of 1994) with marked furrows and ridges on its surface. ${ }^{19}$ Temperature data from two boreholes are available, ${ }^{25}$ one drilled in 1987 (labeled 2/87) and a second one drilled in 2000 (labeled 2/00). Details of the measurements in borehole 2/87 are documented by Vonder Mühll and Haeberli ${ }^{26}$ (depth down to $9.55 \mathrm{~m}$ is used to initialize the model). It should be noted that at a depth of $52 \mathrm{~m}$ evidence of intrapermafrost
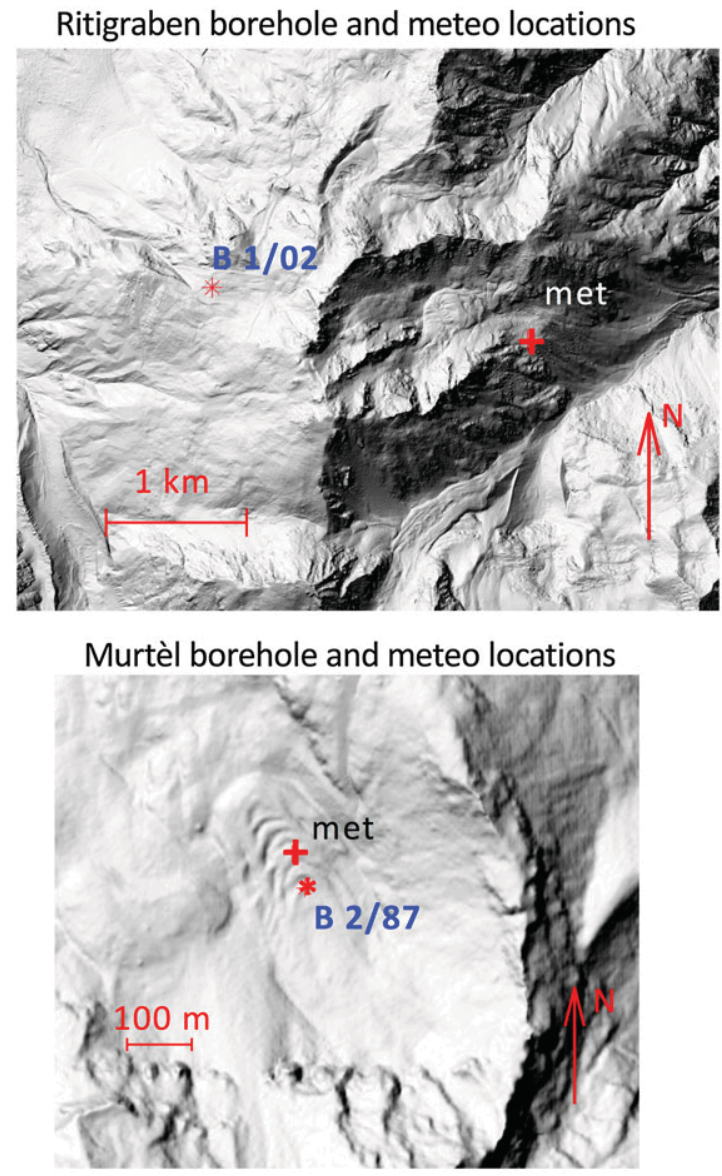

Schafberg borehole and meteo locations
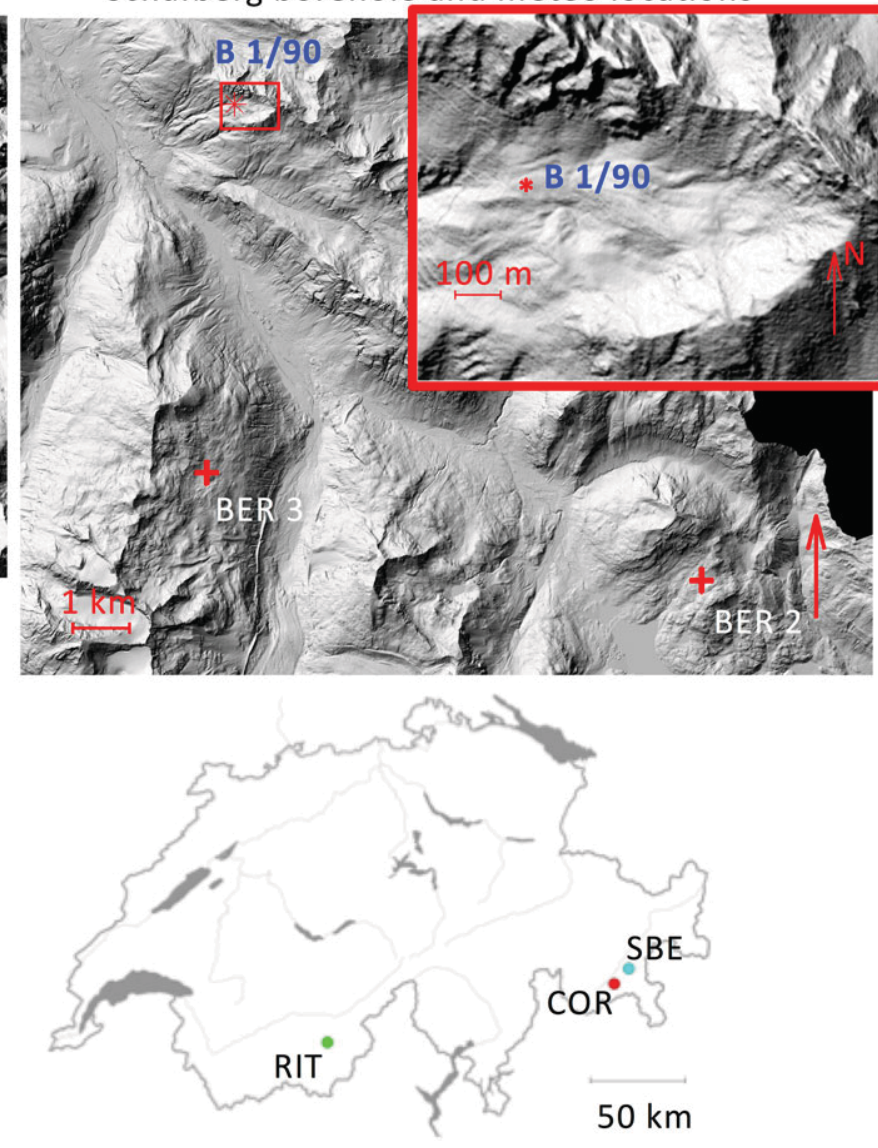

FIGURE 1 Location of borehole and meteorological stations: RIT = Ritigraben, COR = Murtèl-Corvatsch, SBE = Schafberg. The boreholes are located at $\left(2^{\prime} 631^{\prime} 755,1^{\prime} 113^{\prime} 775\right)$ Ritigraben B 1/02, (2'783'175, 1'144'692) Murtèl B 2/87 and $\left(2^{\prime} 790^{\prime} 856,1^{\prime} 152^{\prime} 745\right)$ Schafberg B 1/90. All coordinates in $\mathrm{CH} 1903+/ \mathrm{LV} 95$ standard Swiss coordinate system. Digital elevation model: SwissAlti3D (relief) 
groundwater flow was presented by Vonder Mühll. ${ }^{22}$ This has important consequences for the temperature gradient within the rock glacier and will influence the initialization of temperatures in the model.

Vonder Mühll and Klingerlé ${ }^{19}$ describe the structure of the Murtèl-Corvatsch rock glacier as consisting of four layers, with a 35 -m-thick active layer consisting of mainly granodiorite blocky rock material or boulders, with block sizes of approximately $1 \mathrm{~m}^{2}$ and up to several cubic metres according to Mittaz et al. ${ }^{8}$ Arenson ${ }^{21}$ describes the second layer as consisting to a large extent of ice mixed with sandy or silty material and with a thickness of $20 \mathrm{~m}$. The third layer extends down to $30 \mathrm{~m}$ and consists of ice, silt and sand, and the fourth layer is described as a blocky one, saturated with ice. ${ }^{19}$

For this study only the top $10 \mathrm{~m}$ containing both the blocky layer and part of the icy layer are considered. These layers need to be initialized in SNOWPACK's soil module with the following parameters: volume fraction of water, ice, solid and air, thermal conductivity, density and heat capacity of the solid component, grain size, and temperature. When the soil consists of rock (as in the blocky layer) the grain size is replaced by a flag indicating that the solid fraction consists of blocks. Because the exact conditions and combination of materials at each thermistor are not fully known, some simplifications need to be made, both in the composition and in the extent of the layers. According to borehole data from PERMOS, ${ }^{25}$ the amplitude of temperature changes is largest above $2.55 \mathrm{~m}$ in borehole 2/87 and depths below $2.55 \mathrm{~m}$ remain at temperatures below $0^{\circ} \mathrm{C}$ for most of the time series. Because PERMOS ${ }^{25}$ data were used for validation of the model, preference was given to these values for the model initialization and thus the blocky layer thickness is set to $2.55 \mathrm{~m}$. Extending the blocky layer deeper into the ground would result in modeled zero curtains differing significantly from measured ones. The blocky layer was initialized with an air volume fraction of $40 \%,{ }^{24}$ with the remaining fraction made up of the solid material. The water and ice fractions are set to 0 in the blocky layer. The values for the properties of the solid fraction are as follows: the density ${ }^{24}$ is $\rho=2000 \mathrm{~kg} / \mathrm{m}^{3}$, the thermal conductivity ${ }^{27}$ is $k_{\text {solid }}=2.63 \mathrm{~W} /(\mathrm{mK})$ and the specific heat capacity ${ }^{28}$ is $c_{p}=752 \mathrm{~J} /$ ( $\mathrm{kg} \mathrm{K}$ ). Directly beneath the blocky layer is the icy layer, which consists almost entirely of ice. In the model initialization the volumetric ice content is set to $99 \%$ following Mittaz et al. ${ }^{8}$ who give an estimate of $90-100 \%$. The water and air content is taken as 0 and the density of the remaining fraction ${ }^{19}$ is $950 \mathrm{~kg} / \mathrm{m}^{3}$, the thermal conductivity of the solid soil component ${ }^{29}$ is $0.58 \mathrm{~W} /(\mathrm{m} . \mathrm{K})$ and the specific heat capacity $^{29}$ is $800 \mathrm{~J} /(\mathrm{kg}$. K)

In this study data from borehole $2 / 87$ are used as they provide a longer time series and the meteorological station is closer to this borehole (borehole $2 / 00$ is upslope of borehole $2 / 87$ ). The meteorological station provides the following data: incoming and reflected shortwave radiation, incoming and outgoing longwave radiation, air and surface temperature, relative humidity, wind speed and direction, and snow height at hourly intervals. Details of the instruments and the measurements are given in Hoelzle et al. ${ }^{20}$

\section{2 | Ritigraben}

The Ritigraben rock glacier is situated on a west-facing slope in the Matter Valley in the Western Swiss Alps at an elevation of
$2690 \mathrm{~m}$ a.s.l. with an areal extent of approximately $1.4 \mathrm{~km}^{2}$ (as of 2012) according to Zenklusen Mutter and Phillips. ${ }^{30}$ Thermal data from a borehole drilled in 2002 are available through PERMOS ${ }^{25}$ with details of the measurements given in Herz et al. ${ }^{31}$ Due to a seasonal talik, ${ }^{30}$ with water fluxes through the permafrost ${ }^{32,33}$ at a depth of 12-13 $\mathrm{m}$, the cut-off depth for the model was chosen at $8 \mathrm{~m}$.

The internal structure is roughly given by a blocky layer down to around $2.5 \mathrm{~m}$ with block sizes of approximately $0.5 \mathrm{~m}$ and up to several cubic metres. ${ }^{31}$ Underneath this layer is a mixed layer with finer material and ice lenses followed by a layer with rocks, fine-grained material and ice. $^{30}$ The rocky material consists mainly of augen-gneiss estimated from Geocover, product of the Federal Office of Topography swisstopo, which has a density of about $2400 \mathrm{~kg} / \mathrm{m}^{3}$ and a thermal conductivity of $2.7 \mathrm{~W} /(\mathrm{m} . \mathrm{K})$ according to Sharma. ${ }^{27}$ A specific heat capacity of $850 \mathrm{~J} /$ ( $\mathrm{kg} \mathrm{K}$ ) was used because no measured value was available.

The meteorological station at Ritigraben does not provide reliable data, in particular for snow height, hence the intercantonal measurement and information system (IMIS) meteorological station at nearby Seetal was used ( $2.3 \mathrm{~km}$ east of Ritigraben, at $2480 \mathrm{~m}$ a.s.l.). However, it should be noted that the Seetal station is in a very different orographic setting than the borehole at Ritigraben. The rock glacier is located on a west-facing slope while the meteorological station is located in a cirque with mountain ranges on the north, west and south sides. The predominant wind direction recorded by the IMIS wind station on the Platthorn is north-northwest, which could lead to a discrepancy between the snow heights measured at the Seetal station and the borehole site. The meteorological station at Seetal provides the following data: reflected shortwave radiation, air and surface temperature, relative humidity and snow height. Wind measurements (direction and speed) are available from the wind station on Platthorn at $3246 \mathrm{~m}$ a.s.l.

\section{3 | Schafberg}

The Schafberg rock glacier is located in the Upper Engadine, Eastern Swiss Alps, at an elevation of $2732 \mathrm{~m}$ a.s.l. on a west-facing slope. Two boreholes were drilled in 1990 and thermal data are available through PERMOS. ${ }^{25}$ For this study the borehole labeled $2 / 90$ is used because the other borehole has gaps in the data of several years. Ground temperature measurements for borehole 2/90 are available at $0.0,1.2,3.2,5.2,7.2,9.2,13.217 .2 \mathrm{~m}$ and down to a depth of $25.2 \mathrm{~m}$.

The surface layer is described as being made up of rubble or debris, ${ }^{34}$ and block sizes are smaller than at the other two rock glacier sites (up to $0.5 \mathrm{~m}^{3}$ ). The volumetric ice content between 5 and $12 \mathrm{~m}$ depth is estimated as about $45 \% .{ }^{22}$

There are two meteorological stations which can be used for the Schafberg site. These are the IMIS station Bernina 3 in an east-facing slope, which is closer to the borehole site $(6.3 \mathrm{~km}$ south of Schafberg at $2620 \mathrm{~m}$ a.s.I.), and the IMIS station Bernina 2, which is farther away but has more comparable topography to the borehole site $(11.6 \mathrm{~km}$ south-east of Schafberg at $2450 \mathrm{~m}$ a.s.l.). Distance from the borehole site, elevation and topography can affect how representative the snow height at the meteorological stations is for the borehole. The meteorological stations provide the following data: reflected shortwave 
radiation, air and surface temperature, relative humidity, snow height, and wind speed and direction.

\section{3 | METHODS}

\section{1 | Model}

In SNOWPACK, soil and snow layers are computationally represented by finite elements. Information about the stratigraphy of the rock glacier and temperatures are registered in the soil module during the initialization. The soil domain is split into the blocky and icy layers; for each layer the volume fractions of ice, water, solids and air need to be supplied as discussed above. Additionally, the physical properties (density, thermal conductivity and specific heat capacity) of the solids fraction need to be provided. For finer grained solid material or ice a grain size can be specified (for rock, ie, in the blocky layer, this is omitted). The grain size will determine the field capacity and hence the amount of water that can be retained in a specific layer. The surface of the soil domain, while in reality not clearly defined due to the large blocks and gaps in between, is taken to be located at the elevation given for the borehole (see sections on site descriptions).

The focus of this paper is to investigate the role played by ventilation in modeling the thermal regime of rock glaciers. In SNOWPACK the ventilation is included in a parameterized form, which acts to increase the apparent thermal conductivity of the computational ground (or snow) element. A detailed description of the ventilation parameterization can be found in Lehning et al., ${ }^{17}$ and only a short summary is presented here. A standard logarithmic wind profile is assumed requiring only one wind measurement at a reference height:

$$
U(z)=\frac{u_{*}}{k} \ln \left(\frac{z+d}{z_{0}}\right)
$$

where $u_{*}$ is the friction velocity, $k=0.4$ is the von Karman constant, $z_{0}$ is the roughness length and $d$ is the displacement depth. Originally, the displacement depth is calculated based on the density of each computational snow (soil) element. An amendment has been made for rock glaciers for the snow-free period only; here the displacement depth is taken as a constant because the density of the rocks is constant. For the snow cover the original method is preserved. The friction velocity is computed iteratively from

$$
u *=\frac{k U_{r e f}}{\ln \left(\frac{z_{r e f}+d}{z_{0}}\right)-\Psi}
$$

where an initial value for the roughness length $z_{0}=0.002$ for snow cover $^{35}$ was supplied, $U_{\text {ref }}$ is the measured wind speed at the reference height $z_{\text {ref }}$ and $\Psi$ is a stability correction based on the Monin-Obukhov theory $^{36}$ and calculated following the method of Michlmayr et al. ${ }^{37}$ Further, it is assumed that the effect of the wind-forced ventilation decreases exponentially with depth, such that the velocity of the pore air can be expressed as

$$
U_{p}(z)=U_{0} \exp \left(-C_{e x t} \rho|z|\right)
$$

where $U_{0}$ is the wind speed at the surface calculated from Equation (1),
$C_{\text {ext }}$ is an extinction coefficient, which needs to be calibrated, and $\rho$ is the density of the computational soil element. Based on a mixing length approach a diffusivity for the ventilation effect can be defined as

$$
K_{p}=\alpha L_{p}^{2} \frac{d U_{p}}{d z}
$$

where $L_{p}$ is the effective pore length and $\frac{d U_{p}}{d z}$ is the shear of the pore air. While theoretically $\alpha$ can be understood as the ratio of tortuosity to porosity, in practice it is used as a fitting parameter in the model. The effective or apparent thermal conductivity of the computational soil element is then calculated as the sum of its effective physical heat conductivity, $k_{s}$ (this takes into account the different constituents of the soil element, ie, solid, water, ice and air contents) and the additional component arising from the ventilation, $k_{p}=\rho_{\text {air }} c_{p}$, air $K_{p}$, where $\rho_{\text {air }}$ is the density of air and $c_{p}$, air is the specific heat capacity of air (cf. Equation (4)):

$$
K_{\text {eff }}=k_{s}+k_{p}
$$

The ventilation module in SNOWPACK has originally been developed for snow. Ventilation in snow, however, is small ${ }^{18,38}$ and model parameters need to be chosen for the rocky layer. Therefore, the fitting parameter $\alpha$, the displacement depth $d$ and extinction coefficient $C_{\text {ext }}$, which are considered site-independent, have been calibrated using data from Murtèl. This site was chosen for calibration because (i) the meteorological station is close to the borehole, thus providing reliable forcing data, and (ii) the stratigraphy of the rock glacier is well known, thus limiting the amount of uncertainty introduced. This leaves the pore length $L_{p}$ as the only parameter of the ventilation module that needs to be adjusted for each site. The pore length is dependent on the block size, which will vary between sites, with a larger pore length corresponding to a larger block size. This method does not distinguish between different mechanisms of heat transport, which might be active during seasonal warming or cooling periods, and does not account for lateral components such as water or air fluxes. If lateral components are important, they would need to be included explicitly by specifying an advective heat flux for each time step in the forcing data. ${ }^{14}$

The model was run in two different configurations: standard (ie, no ventilation, achieved by setting $\alpha$ to zero for both snow-free and snow-covered periods) and with added ventilation. Model runs showing the effect of ice content have been performed for Murtèl and model runs showing the effect of snow height have been performed for Ritigraben and Schafberg.

\section{2 | Forcing data}

To run the SNOWPACK model, hourly meteorological forcing data are required, so any gaps in the data need to be filled. Short gaps (up to $3 \mathrm{~h}$ ) were filled by using linear interpolation between the previous and subsequent time steps. For longer gaps this method would lead to the loss of the diurnal cycle and a different method was used. An average site-specific daily cycle was computed for every month of the year using all available data at the site. Data from this average daily cycle were then used to fill the gaps. For Murtèl, Ritigraben, 
and Schafberg the above procedures were applied for 10-15, 1-13 and $1-12 \%$ of all data in the time series (depending on the meteorological variables), respectively. The longest gap in the data for Murtèl was 110 days during the last year of the modeling period.

At Murtel the meteorological station is located close to the borehole and data can be considered representative for the local borehole conditions. The meteorological stations used for the Ritigraben and Schafberg sites are located several kilometers away from the boreholes and may not be fully representative. In particular, snow conditions can vary considerably from one location to another even over relatively short distances because snow cover not only depends on the amount of precipitation but also on wind conditions. The latter can lead to snow drift, particularly on rough surfaces such as rock glaciers, and the snow height may thus be locally reduced or increased. Snow height is a determining factor for the presence of permafrost ${ }^{7}$ and especially permafrost temperatures. Thus, care needs to be taken when using snow height measurements taken from some distance away. Furthermore, snow height measurements are notoriously difficult due to wind conditions causing snow drift and are here further complicated due to an uneven surface. However, the error introduced due to measuring angle and the slope of the surface is small $(\sim 2 \%)$ because the slope here is not very large $\left(\sim 10^{\circ}\right)$.

Due to the differences in topography at the Ritigraben borehole and at the Seetal meteorological station, the measured snow height was not representative. A modeled borehole temperature that is higher than the measured one could indicate that the snow height is excessive and vice versa. The Ritigraben borehole has closely spaced temperature measurements near the surface at 10, 20 and $40 \mathrm{~cm}$ depth. Measurements at these depths were compared to the model output, with the snow height being scaled by a constant factor for each year, and the root mean square error (rmse) was minimized to determine this constant factor. To determine each factor the model was run for the corresponding year with a 1 year spin up period. In general, the effect of this factor is to dampen the year-to-year variability in snow heights.

For the Schafberg site the snow height between the stations Bernina 2 and 3 differs significantly, so both stations have been used separately and using a weighted average of the snow heights. In the latter case, higher weight was given to Bernina 2 due to the similarities in topography with the borehole site.

\section{3 | Boundary conditions}

The upper boundary condition for all model runs is set to switch between Dirichlet (measured temperature) and Neumann (heat flux). Dirichlet and Neuman are used for temperatures below and above $-1.3^{\circ} \mathrm{C}$, respectively, following Lehning et al. ${ }^{17}$ Turbulent heat fluxes are calculated using the bulk transfer method $\left(\mathrm{eg}^{39}\right)$. At the surface, specifically, the equations used by SNOWPACK ${ }^{17}$ are as follows:

$$
\begin{gathered}
\mathrm{Q}_{s}(0)=-C \rho_{a} c_{p}\left(T\left(\mathrm{z}_{\text {ref }}\right)-T(0)\right), \\
\mathrm{Q}_{\mathrm{I}}(0)=-C \frac{0.622 L^{\mathrm{w} / \mathrm{i}} \rho_{a}}{p_{a}}\left[e_{s}^{\mathrm{w}}\left(T\left(\mathrm{z}_{\mathrm{ref}}\right)\right) R H-e_{s}^{\mathrm{i}}(T(0))\right],
\end{gathered}
$$

where $\rho_{a}$ is the density of air, $c_{p}$ is the specific heat capacity of air,
$T\left(z_{\text {ref }}\right)$ is the temperature measured at the reference height $z_{\text {ref }}, T(0)$ is temperature at the surface, $L^{w / i}$ is the latent heat of vaporization or sublimation, respectively, $p_{a}$ is air pressure, $e_{s}^{w}$ is the saturation vapor pressure over water, $e_{s}^{i}$ is the saturation vapor pressure over ice, $R H$ is the relative humidity and the coefficient $C$ is given by:

$$
C=\frac{k u_{*}}{\ln \left(\frac{z_{\text {ref }}}{z_{0}}\right)-\Psi}
$$

where $k=0.4$ is the von Karman constant, $u_{*}$ is the friction velocity, $z_{0}$ is the roughness length and $\Psi$ is the stability correction.

The lower boundary condition for the Murtèl and Ritigraben sites was set to Neumann with a constant heat flux of $0.06 \mathrm{~W} / \mathrm{m}^{2}$, which is the standard value used in SNOWPACK and corresponds to an average geothermal heat flux. This low heat flux has only a minor influence on the simulations. For Schafberg, Dirichlet boundary conditions were specified. The lower boundary of the model domain is set to $9.55 \mathrm{~m}$ for Murtèl, $8 \mathrm{~m}$ for Ritigraben and $17.2 \mathrm{~m}$ for Schafberg. At Ritigraben and Murtèl the cut off was chosen to avoid the influence of taliks, which are located at 12-m depth at Ritigraben and $52 \mathrm{~m}$ at Murtèl. At Schafberg the cut off reflects the depth of zero annual amplitude with nearly constant ground temperature.

Note that the surface of the active layer, which consists of large boulders, and also the base of the snow cover are set at the elevation of the borehole location given by PERMOS. ${ }^{25}$ This simplification was necessary because it is not possible to account for different surface heights attributed to large boulders in the model.

\section{4 | Error measure}

The measured temperature ranges vary significantly at different depths. To make it easier to compare the model performance at different depths, the rmse (calculated from the difference between measured and modeled borehole temperatures) is normalized by the temperature range measured for each depth. The normalized rmse (nrmse $=\operatorname{Sart}\left(\frac{\sum\left(T_{\text {model }}-T_{\text {meas }}\right)^{2}}{n}\right) /(\Delta T)$, where $\Delta T$ is the range of measured temperatures) can then be compared for different depths and sites. This also ensures that the error measure is not dominated by the highly variable surface temperature but adequately represents temperature deviations at larger depths, which are smaller in magnitude but more persistent.

\section{4 | RESULTS}

\section{1 | Murtèl}

The Murtèl site was used to calibrate the ventilation parameters: $\alpha, d$ (for the snow free blocky layer) and $C_{\text {ext }}$. Values of 0.001, 0.1 and 0.002 , respectively, were found to produce reliable model results. Pore length is not included in the calibration as it was allowed to vary between sites to account for differences in block size and thus pore spaces between the blocks. For the Murtèl site best results were obtained for $L_{p}=0.5$. 
Figures $2 \mathrm{a}$ and $2 \mathrm{~b}$ show the model runs with ventilation, without ventilation and with reduced ice content in the icy layer. At $50 \mathrm{~cm}$ depth (Figure 2a) the low winter temperatures are only achieved with ventilation and high ice content. In contrast, the high summer temperatures seem to be less affected by ventilation or ice content. At $250 \mathrm{~cm}$ depth (Figure 2a) both high and low temperatures are more extreme in the model than in the measured data. This depth is where the model performs worst, and this is probably related to the presence of the boundary between blocky and icy layers. This is of course a simplistic set up and a more realistic one might include a transitional layer between the blocky and icy layers accounting for the actual depth and composition of the active layer. At $350 \mathrm{~cm}$ depth (Figure 2b) the case with ventilation shows good agreement between modeled and measured temperatures, as well as good agreement between the timing and duration of zero curtains during phase changes within the active layer in spring and autumn. For the cases with reduced ice content and no ventilation the modeled zero curtains extend into the period where subzero temperatures were measured. Generally, the rate of warming is better represented than the rate of cooling. The cooling process occurs at a slightly slower rate than warming. Once temperatures start to increase, they do so rapidly until they reach $0^{\circ} \mathrm{C}$. At $750 \mathrm{~cm}$ (Figure 2b) modeled temperatures without ventilation are
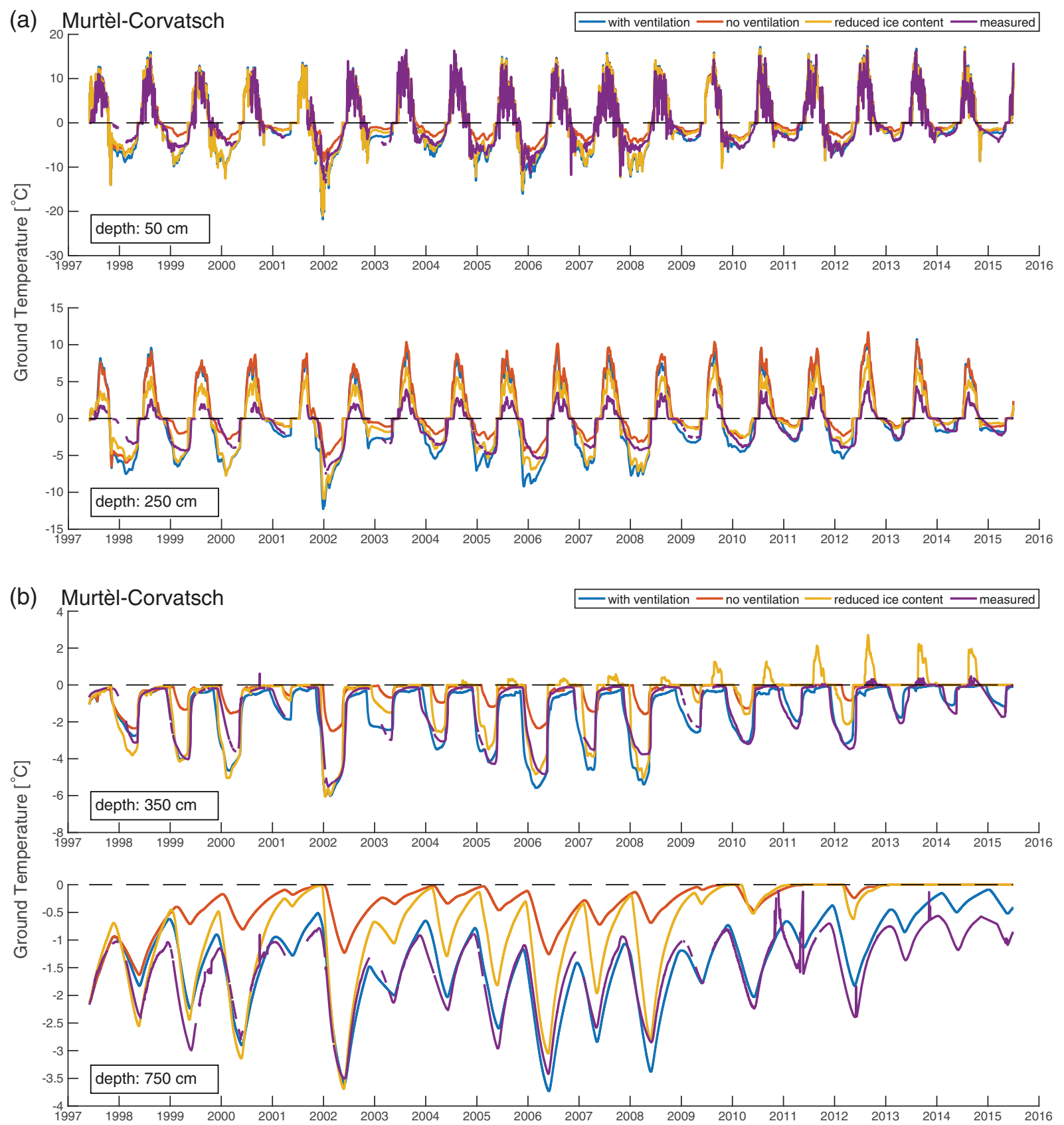

FIGURE 2 (a) Modeled temperatures at depths of 0.5 and $2.5 \mathrm{~m}$ (from top to bottom) for the Murtèl site with the following configurations: ventilation switched on (blue) and ventilation switched off (red); ventilation switched on using a reduced ice content of 70\% in the icy layer (orange). Measured borehole temperatures are shown in purple. (b) Modeled temperatures at depths of 3.5 and $7.5 \mathrm{~m}$ (from top to bottom) for the Murtèl site with the following configurations: ventilation switched on (blue) and ventilation switched off (red); ventilation switched on using a reduced ice content of $70 \%$ in the icy layer (orange). Measured borehole temperatures are shown in purple 
consistently higher than measured ones by as much as $2^{\circ} \mathrm{C}$. The case with lower ice content is slightly better than the case without ventilation but its agreement deteriorates over time. The ventilation case produces the best results. Overall, the results show that both ventilation and a high ice content are necessary to reproduce the low temperatures measured in the icy layer. From 2010 onwards, modeled temperatures without ventilation or with reduced ice content show positive values instead of the measured zero curtains at $3.5 \mathrm{~m}$ depth.

Note that the effect of the lower ice content becomes more apparent over longer model runs. As it allows for melting at the boundary between blocky layer and icy layer, the effect becomes cumulative and modeled temperatures increasingly deviate from measured ones the longer the model is run. This result is of particular importance when running the model to make future projections of permafrost evolution as an error in the initialized ice content can lead to significant deviations in predicted ground temperatures. Reducing the volumetric ice content from $99 \%$ to $70 \%$ increases the average rate of warming relative to measured ground temperatures in the icy layer (calculated over the whole model period at $7.5 \mathrm{~m}$ depth) from $0.08^{\circ} \mathrm{C} /$ decade to $0.50^{\circ} \mathrm{C} /$ decade. Note that the rate of warming due to the reduced ice content is dampened by the extended zero curtain in the modeled temperatures at this depth.

Apart from the ice content, the porosity (or void volume fraction) and the grain size (which determines the field capacity) are of major importance in the soil initialization. These properties determine how much water can infiltrate and be retained in the system. The amount of water in the system will greatly influence the ground thermal regime due the latent heat involved in phase changes.

\section{2 | Ritigraben}

The above described calibration for the ventilation module is used for the Ritigraben site, with a pore length of 0.5 in the top layer and 0.3 in the intermediate layer. In the top part of the blocky layer both Murtèl and Ritigraben have comparable block sizes. The stratigraphy for Ritigraben was less well known than for Murtèl and had to be inferred from model results. It was found that using a 2-m-thick coarse blocky layer with a $1.5-\mathrm{m}$-thick intermediate layer with smaller blocks and an ice-rich layer below worked well. The porosity was set to 0.3 in the upper blocky layer and to 0.1 in the intermediate layer. The volumetric ice content in the ice rich layer was set to $80 \%$.

Model runs with the adjusted and unadjusted snow height and ventilation switched on are presented in Figures $3 a$ and $3 b$. It can be seen that the snow height adjustments improve modeled temperatures at all depths, strengthening the argument that the issue lies indeed with the snow height and is not caused by an incorrect stratigraphy or parameterization in the model. Using the measured snow height directly results in poor agreement between modeled and measured temperatures at all depths during the cold winter period. Generally, if the temperature is too low (high) near the surface, it is also too low (high) at the other depths. Adjusting the snow height by a constant factor for each year to minimize the rmse at the top three measurements $(10,20$ and $40 \mathrm{~cm})$ results in an improved agreement between measured and modeled ground temperatures at all modeled depths. The timing of the warming period and the start of the zero- curtains are well represented by the model. In most years the onset of the cooling period is also well captured by the model. However, in some years the onset of cooling occurs later in the model than in the measurements, most notably in 2013 and 2015. In both cases the adjustment of snow height has improved the model results slightly but the timing is not quite correct. This is probably due to the timing of the snow cover at the borehole site differing from that observed at the meteorological station. The timing of the snow cover has not been taken into account when making adjustments to the snow height. Staub and Delaloye ${ }^{40}$ have proposed a method to calculate snow insulation and melt indices from near-surface ground temperature data which could be used to adjust for the timing of the snow cover in future work.

Modeled temperatures for model runs with and without ventilation can be seen in Figures $3 \mathrm{a}$ and $3 \mathrm{~b}$. This clearly shows that without ventilation the modeled temperatures do not match the measured ones. In particular, ventilation appears necessary to model the low temperatures. Without ventilation effects the low winter temperatures measured cannot be reproduced by the model; throughout the modeled period and at all depths modeled temperatures are too high by up to several degrees compared to measured ones. Without ventilation a delay in the onset of the cooling period can be observed in the modeled temperatures, which increase as model time passes. From 2010/11 onwards the modeled temperatures remain constant at $6 \mathrm{~m}$ depth and at $3.5 \mathrm{~m}$ depth winter temperatures remain constant at $0^{\circ} \mathrm{C}$, while summer ground temperatures rise above zero without ventilation. Using ventilation, a good agreement between modeled and measured temperatures can be achieved. This shows that ventilation processes are crucial in maintaining the low temperatures in the Ritigraben rock glacier.

It is interesting to note that the warm periods are less affected by the lack of ventilation, indicating that it is the cooling which is most affected by the presence of a blocky layer. This observation is in line with the cooling effect of coarse rock layers noted by Guodong et al. ${ }^{3}$ or Gruber and Hoelzle. ${ }^{41}$

\section{3 | Schafberg}

The same calibration of the ventilation parameters as for the previous two sites is also used at Schafberg. Here, however, the pore length is significantly reduced due to the smaller block size, with values of 0.2 in the top layer and 0.1 in the intermediate layer. Additionally, the top layer in the model is very thin $(10 \mathrm{~cm})$ and only contains the uppermost borehole temperature measurement. The intermediate layer is set to a thickness of $3.1 \mathrm{~m}$ with an air fraction of 0.05 . To reproduce measured temperatures, it was also necessary to include a water volume fraction of 0.05 . This is in contrast to the other two sites where no water was included in the upper layers during the initialization. It is assumed that the finer grained blocky layer here is able to retain more water than the coarse blocky structure at the other sites. In the icy layer the ice content was set to $50 \%$, which is lower than at the other two sites where lower borehole temperatures at or below $0^{\circ} \mathrm{C}$ indicated a higher ice content.

The model was run with different setups of forcing data: firstly using both stations separately and then using a weighted average of snow heights from both stations. Snow heights at Bernina 2 were 

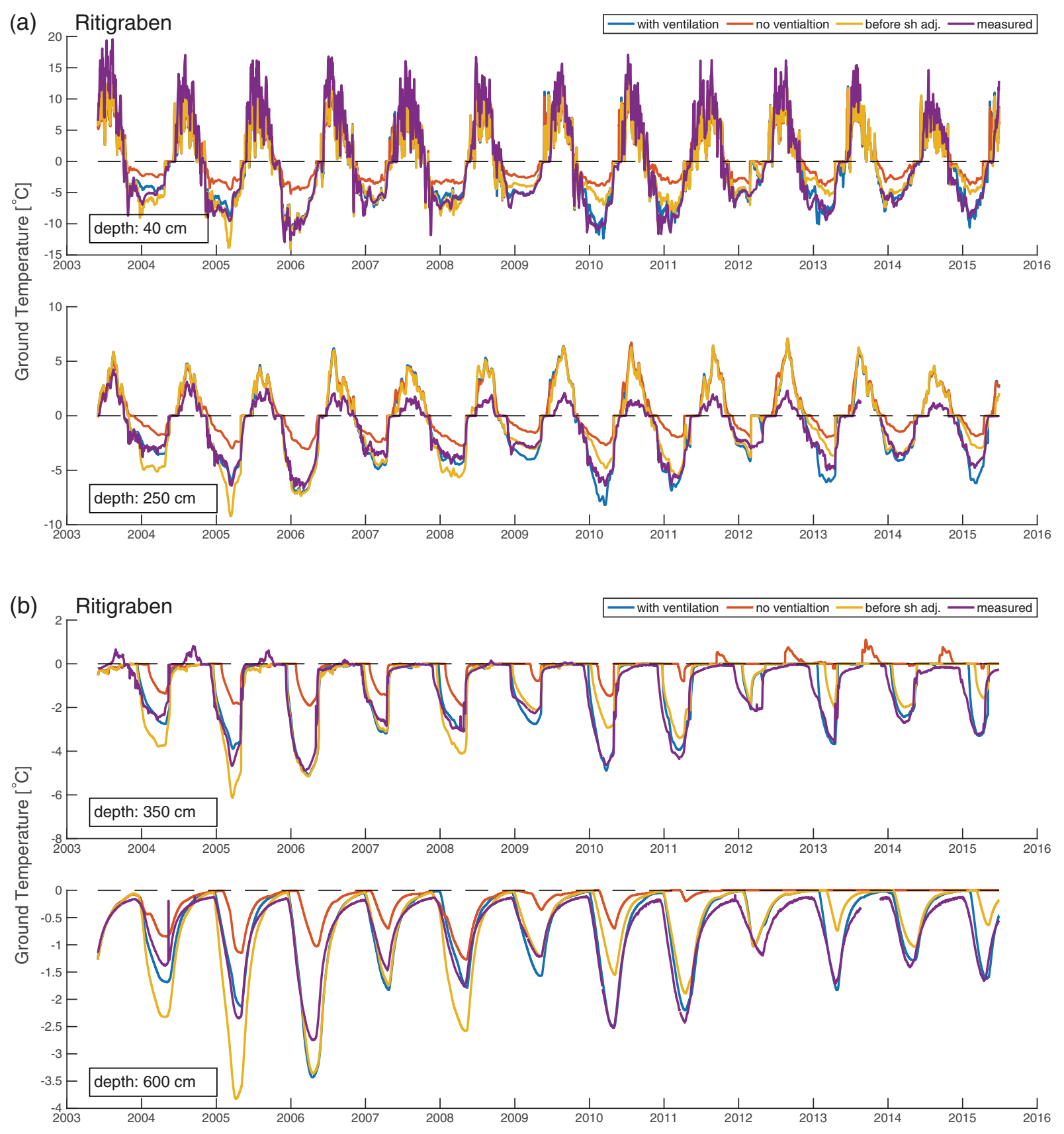

FIGURE 3 (a) Modeled temperatures at depths of 0.4 and $2.5 \mathrm{~m}$ (from top to bottom) for the Ritigraben site with the following configurations: ventilation switched on (blue) and ventilation switched off (red), both cases using the adjusted snow height; ventilation switched on using unadjusted snow height (orange). Measured borehole temperatures are shown in purple. (b) Modeled temperatures at depths of 3.5 and $6.0 \mathrm{~m}$ (from top to bottom) for the Ritigraben site with the following configurations: ventilation switched on (blue) and ventilation switched off (red), both cases using the adjusted snow height; ventilation switched on using unadjusted snow height (orange). Measured borehole temperatures are shown in purple

generally lower than at Bernina 3, resulting in lower modeled ground temperatures in the run using forcing data from Bernina 2. In particular, modeled winter temperatures are significantly lower than measured ones in this case. Using snow data from Bernina 3, by contrast, results in higher modeled ground temperatures, with temperatures remaining constant at $0^{\circ} \mathrm{C}$ at $7.2 \mathrm{~m}$ depth in the latter half of the modeled period. Therefore, neither station gave a good agreement between modeled and measured temperatures on its own. An adapted snow height obtained by weighting the data of Bernina 2 and Bernina 2 with factors of 0.9 and 0.1 , respectively, resulted in an improved overall agreement between modeled and measured ground temperatures.
Figures $4 \mathrm{a}$ and $4 \mathrm{~b}$ show the modeled ground temperatures for model runs with and without ventilation. The model run without ventilation cannot reproduce the low temperatures measured during the snow-covered period. This can be seen particularly well at 3.2 and $7.2 \mathrm{~m}$ depth. The low temperatures are much better represented in the case with ventilation. However, modeled temperatures tend to be slightly too high near the surface and too low at greater depth. This could indicate that the stratigraphy is not realistic. However, due to the wide spacing between thermistors it was not possible to infer a more detailed stratigraphy. The rate and timing of the thawing process in spring are generally better represented than the cooling process in 

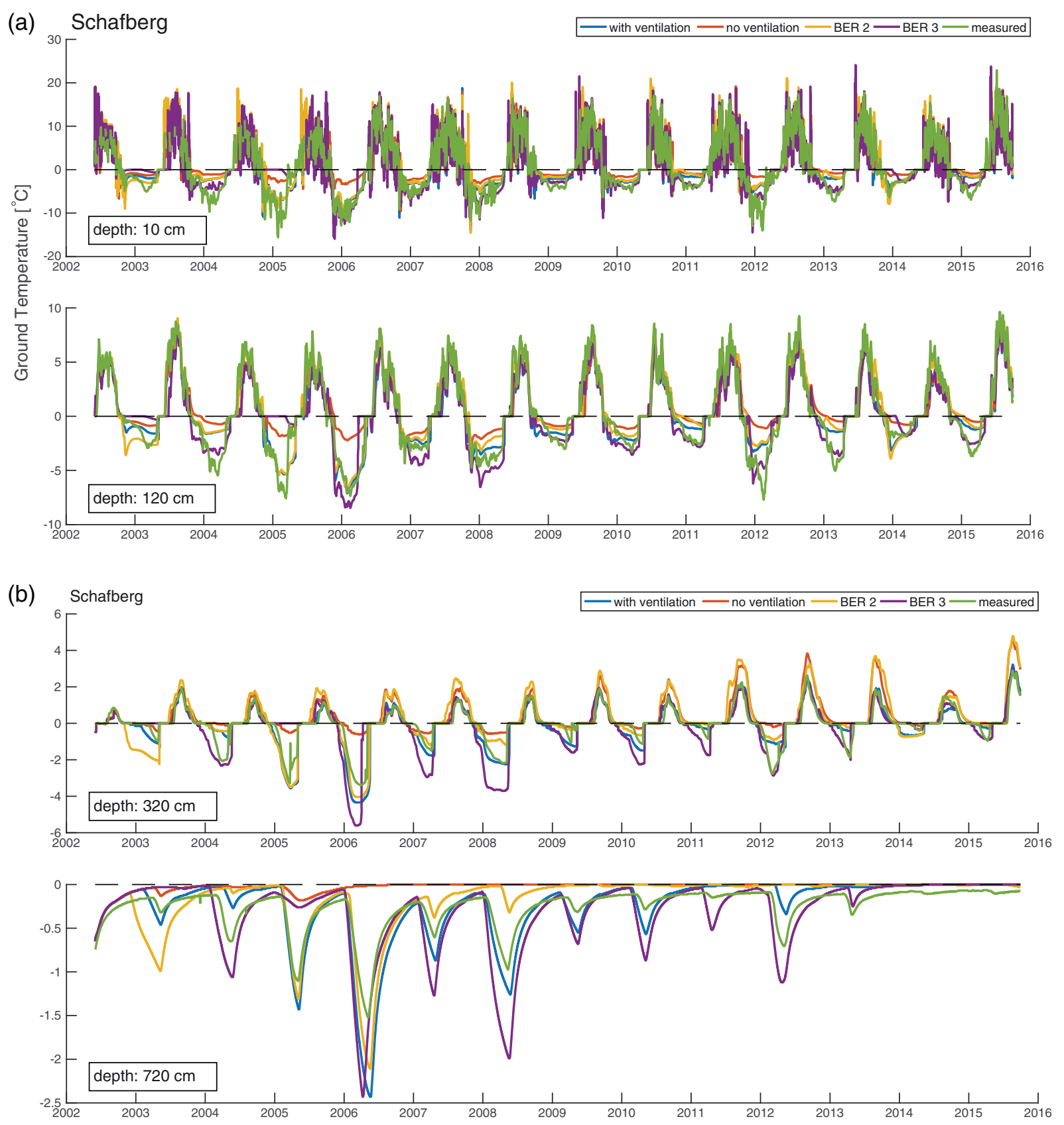

FIGURE 4 (a) Modeled temperatures at depths of 0.1 and $1.2 \mathrm{~m}$ (from top to bottom) for the Schafberg site with the following configurations: ventilation switched on (blue) and ventilation switched off (red), both cases using the adjusted snow height; ventilation switched on with snow height data from station Bernina 2 (orange) and with snow height data from Bernina 3 (purple). Measured borehole temperatures are shown in green. (b) Modeled temperatures at depths of 3.2 and $7.2 \mathrm{~m}$ (from top to bottom) for the Schafberg site with the following configurations: ventilation switched on (blue) and ventilation switched off (red), both cases using the adjusted snow height; ventilation switched on with snow height data from station Bernina 2 (orange) and with snow height data from Bernina 3 (purple). Measured borehole temperatures are shown in green

autumn. The modeled cooling often occurs too early and is more rapid than observed. This could indicate incorrect water content or grain size values.

Table 1 shows the nrmse for each site for the model run with ventilation at the depth shown in Figures 2-4. Generally, the error is about 0.1 , with the most notable exception being $2.55 \mathrm{~m}$ at Murtèl where the nrmse is doubled. This exception could be caused by the presence of the boundary between the blocky layer and the icy layer at this depth. In the model the boundary is clearly defined, whereas in nature a gradual transition-possibly varying in time-can be expected. The other exception is Schafberg at $7.2 \mathrm{~m}$ with an nrmse of 0.15 , which may be due to the inadequate representation of the stratigraphy in the model.

\section{5 | DISCUSSION}

The results showed sensitivity to several parameters in terms of both forcing data and soil initialization. The most important variable in the forcing data is snow height, which plays a major role due to the thermal 
TABLE 1 Normalized root mean square error for each study sites at four depths (near-surface in the blocky layer, lower part of blocky layer, upper part of icy layer, mid or lower part of icy layer), the depths vary between sites as measurement depths and intervals are not consistent across sites

\begin{tabular}{|c|c|c|c|c|}
\hline & $\begin{array}{l}\text { Depth at COR/RIT/ } \\
\text { SBE }\end{array}$ & & & \\
\hline Location & & COR & RIT & SBE \\
\hline Blocky layer, near surface & $0.55 \mathrm{~m} / 0.4 \mathrm{~m} / 0.1 \mathrm{~m}$ & 0.08 & 0.08 & 0.09 \\
\hline Blocky layer, lower part & $2.55 \mathrm{~m} / 2.5 \mathrm{~m} / 1.2 \mathrm{~m}$ & 0.21 & 0.14 & 0.09 \\
\hline Icy layer, upper part & $3.55 \mathrm{~m} / 3.5 \mathrm{~m} / 3.2 \mathrm{~m}$ & 0.10 & 0.09 & 0.08 \\
\hline Icy layer, mid or lower part & $7.55 \mathrm{~m} / 6.0 \mathrm{~m} / 7.2 \mathrm{~m}$ & 0.10 & 0.08 & 0.15 \\
\hline
\end{tabular}

properties of snow. On the one hand, snow has a low thermal conductivity, which insulates the underlying ground at high snow depths. On the other, its high emissivity and high albedo can lead to radiative cooling. The latter effect dominates for snow depths below $60-80 \mathrm{~cm}$ (see eg, ${ }^{16,42}$ ). The timing of the snow cover will also influence the ground thermal regime. Both early thin snow cover in autumn ${ }^{43,44}$ and long lasting snow cover in spring will contribute to cooling, the former through radiative cooling and the latter by providing a heat sink during snowmelt. ${ }^{45}$ This will have implications for climate change-induced shifts in the timing and amount of snow precipitation and could be of particular interest when investigating rock glacier evolution. It may be possible that future atmospheric warming could be offset by less snow precipitation and changes in the timing of snow cover.

For the soil initialization, several parameters are important: blocky surface layer thickness, porosity and ice content. The thickness and thermal characteristics of the blocky layer affect the depth at which the zero curtains occur in the model. In combination with the pore length, the blocky layer thickness also determines the depth and effectiveness of the ground ventilation. The porosity (and field capacity or grain size) affects the water transport and amount of water that can be retained in each layer. This is important as water content has a significant effect on the ground thermal regime due to large amounts of latent heat required or released during phase changes. Water infiltration during snowmelt increases thaw rate in spring while water retention increases the length of zero-curtains. Finally, the ice content of the icy layer is a sensitive parameter because of its high enthalpy of fusion. An underestimation of the ice content can result in a false indication of permafrost thaw. More closely spaced borehole temperature measurements make it easier to determine the stratigraphy. It is also useful to have information from borehole cores about the ice content and the grain size in the icy layer as the example at Murtèl has shown. It can take upwards of 10 years for an incorrect ice content in the model to show significant deviations from observations. Thus, if ice content is not exactly known, long-term temperature data series are needed for calibration to prevent an incorrect ice content from causing the modeled temperatures to drift artificially. However, long-term borehole temperature series may not always be available for calibration and longer term drifting of modeled temperature may thus not be detected. This issue becomes particularly important when considering future projections that span over several decades or even centuries.

Ventilation was shown to be important in all three cases. It was necessary to reproduce the low ground temperatures measured during the snow-covered period in winter. Thus, the ventilation in the snow cover is particularly important. The large rocks or boulders on the surface of rock glaciers prevent the formation of a smooth snow cover; instead it is interspersed with these blocks. This allows for ventilation to penetrate into the snow cover and into the blocky layer.

Three important limitations to the current study need to be considered. Firstly, only a limited number of test sites was addressed. Among these Murtèl and Ritigraben have similar characteristics, while Schafberg has smaller block sizes and thus a reduced pore length. In all cases blocky layer thickness and rock glacier stratigraphy were comparable. If these deviate significantly, calibration may need to be adjusted, eg, the displacement depth or the extinction coefficient. Secondly, lateral effects such as air or water fluxes are not taken into account by SNOWPACK. It is possible for ventilation and water fluxes to occur laterally (as has been observed at $12 \mathrm{~m}$ depth in the Ritigraben rock glacier ${ }^{14}$ ), and the process can be expected to be particularly important for either steep slopes due to elevation-induced temperature differences or for larger block sizes, which allow for larger pore lengths. Thirdly, water sources other then melting of the ice contained within the soil or the snow cover are not taken into account. These could include summer precipitation because the model is forced using snow height and water from springs or other lateral inflow of water. Including springs or lateral inflow of water would prove difficult as information on location and quantity are not readily available. Additionally, including springs or lateral inflow is not currently supported in the model. Including summer precipitation may lead to an over-estimation of the water content in the system because lateral outflow is not accounted for. Ground temperatures in the icy layer are reasonably well represented in the current model setup during summer months, and thus other processes might be compensating for the lack of summer precipitation.

The main difficulties in the modeling process were encountered in the boundary region between the blocky and icy layers, and due to a limited number of measurements in the blocky layer. The boundary region between blocky and icy layer showed the largest error in the model with nrmse being considerably higher (typically around 0.2) than in other layers (with typical values around 0.1). The transition between the blocky layer and icy layer represents a discontinuity in the physical characteristics supplied to the model, which could cause computational difficulty. It could also be possible that the transition between layers differs in reality to the setup in the model, although it is not possible to know the exact conditions at any specific point. Furthermore, it might be possible that the layer varies with time because melting and freezing occurs at the upper level of the permafrost boundary ${ }^{24}$ and sediments may get flushed in or out. It is also possible for meteoric water to influence the uppermost layer of the permafrost. ${ }^{46,47}$

The highest temporal temperature variations and vertical temperature gradients can be observed in the blocky layer. It is therefore useful to have more closely spaced temperature sensors in this layer to improve the soil initialization, resulting in a more representative stratigraphy. The bias between modeled and measured temperatures (not shown) was not consistently positive or negative at all depths at a given site, which may be due to several reasons. Firstly, the stratigraphy is not exactly known and must be inferred from comparing 
model output to measured temperatures and larger distances between measurements lead to more uncertainty in the stratigraphy. Secondly, the real physical ventilation processes are not exactly modeled; instead they are only represented in one dimension in a parameterized form and thus lateral effects are not accounted for. Thirdly, lateral effects could also differ between layers.

Some interesting consequences of the present results should be noted. Due to the sensitivity of ground temperatures to the snow height it may be possible to infer the snow height if all other forcing data and ground stratigraphy are well known. A conceivable process might involve solving iteratively for snow height. However, such a process would become computationally expensive over longer modeling periods. Where the stratigraphy is not well known but good quality forcing data and closely spaced ground temperature measurements are available, the stratigraphy can be inferred from the model: inparticular, the approximate extent of the blocky layer and the depth at which the icy layer begins.

\section{6 | CONCLUSIONS AND OUTLOOK}

The most important outcomes of this study can be summarized as follows:

- For coarse blocky layers, such as found at the Murtèl and Ritigraben sites and also for smaller block sizes as found on Schafberg, ventilation proved to be pivotal for modeling the low temperatures in the icy layer. Ventilation is of particular importance during the snowcovered period. Without ventilation, ground temperatures were overestimated, especially over long time periods.

-The model setup can be used to study the future evolution of rock glaciers under different climate change scenarios: results indicate that a reduced snow cover in early winter might lead to a decrease in ground temperatures in rock glaciers.

-Sites with lower ice content may be more susceptible to melt as the results for Murtèl have shown: the case with reduced ice content leads to ice melt and increased temperatures under the same meteorological conditions, whereas the higher ice content remained at the lower temperatures that have been measured.

- Long calibration periods are necessary if the physical characteristics of the rock glacier at the start of the modeling period are not exactly known. In particular, good estimates of ice content are essential to reliably model the thermal regime in the icy layer.

Future work will investigate the three sites presented in this paper under different climate scenarios and aim to make projections of future permafrost evolution in these areas. The results will be used to study under which conditions the ice could be a potential source of water.

\section{ACKNOWLEDGEMENTS}

The borehole data were obtained from the PERMOS network (http:// www.permos.ch). The meteorological data at Ritigraben and Schafberg were obtained from the Swiss IMIS network. Michel Bovay is thanked for providing these data. We would also like to acknowledge all persons involved during the field campaigns on the three sites that we considered. Finally, we would like to thank the reviewers for their positive and constructive feedback.

\section{ORCID}

Luisa Pruessner (1D) http://orcid.org/0000-0001-8125-2426

\section{REFERENCES}

1. Huss M, Hock R. A new model for global glacier change and sea-level rise. Front Earth Sci. 2015;3:54. https://doi.org/10.3389/feart.2015.00054

2. Kenner R, Magnusson J. Estimating the effect of different influencing factors on rock glacier development in two regions in the Swiss Alps. Permafrost Periglac Process. 2017;28(1):195-208. https://doi.org/ 10.1002/ppp.1910

3. Guodong C, Yuanming L, Zhizhong S, Fan J. The "thermal semi-conductor" effect of crushed rocks. Permafrost Periglac Process. 2007;18(2):151-160. https://doi.org/10.1002/ppp.575

4. Barsch D. Rockglaciers. Chichester, UK: Wiley; 1988.

5. Bliss A, Hock R, Radić V. Global response of glacier runoff to twentyfirst century climate change. Case Rep Med. 2014;119(4):717-730. https://doi.org/10.1002/2013JF002931

6. Unger-Shayesteh K, Vorogushyn S, Farinotti D, et al. What do we know about past changes in the water cycle of central Asian headwaters? a review Glob Planet Change. 2013;110:4-25. https://doi.org/ 10.1016/j.gloplacha.2013.02.004

7. Hoelzle M, Mittaz C, Etzelmüller B, Haeberli W. Surface energy fluxes and distribution models of permafrost in European mountain areas: an overview of current developments. Permafr. Periglac. Process. 2001;12(1):53-68

8. Mittaz C, Hoelzle M, Haeberli W. First results and interpretation of energy-flux measurements over Alpine permafrost. Ann Glaciol. 2000;31:275-280. https://doi.org/10.3189/172756400781820363

9. Stocker-Mittaz C, Hoelzle M, Haeberli W. Modelling alpine permafrost distribution based on energy-balance data: a first step. Permafr. Periglac. Process. 2002;13(4):271-282. https://doi.org/10.1002/ppp.426

10. Fierz C, Riber P, Adams EE, et al. Evaluation of snow-surface energy balance models in alpine terrain. J Hydrol. 2003;282(1-4):76-94. https://doi.org/10.1016/S0022-1694(03)00255-5

11. Wakonigg H. Unterkühlte Schutthalden, Beiträge zur Permafrostforschung in Österreich. Arbeiten aus dem Institut für Geographie der Karl-Franzens-Universität Graz. 1996;33:209-223.

12. Hanson S, Hoelzle M. The thermal regime of the active layer at the Murtel Rock Glacier based on data from 2002. Permafrost Periglac Process. 2004;15(3):273-282. https://doi.org/10.1002/ppp.499

13. Wicky J, Hauck C. Numerical modelling of convective heat transport by air flow in permafrost-affected talus slopes. Cryosphere. 2016;11:1311-1325. https://doi.org/10.5194/tc-2016-227

14. Luethi R, Phillips M, Lehning M. Estimating non-conductive heat flow leading to intra-permafrost Talik formation at the Ritigraben Rock Glacier (Western Swiss Alps). Permafrost Periglac Process. 2017;28(1):183-194. https://doi.org/10.1002/ppp.1911

15. Neid DA, Bejan A. Convection in Porous Media. Berlin, Germany: Springer; 2013.

16. Luetschg M, Lehning M, Haeberli W. A sensitivity study of factors influencing warm/thin permafrost in the Swiss Alps. J Glaciol. 2008;54(187):696-704. https://doi.org/10.3189/002214308786570881

17. Lehning M, Bartelt P, Brown B, Fierz C. A physical SNOWPACK model for the Swiss avalanche warning Part III: meteorological forcing, thin layer formation and evaluation. Cold Reg Sci Technol. 2002;35(3):169-184. https://doi. org/10.1016/S0165-232X(02)00072-1

18. Bartlett SJ, Lehning M. A theoretical assessment of heat transfer by ventilation in homogeneous snowpacks. Water Resour Res. 2011;47(4). W04503. DOI: https://doi.org/10.1029/2010WR010008 
19. Vonder Mühll DS, Klingelé EE. Gravimetrical investigation of ice-rich permafrost within the rock glacier Murtel-Corvatsch (upper Engadin, Swiss Alps). Permafrost Periglac Process. 1994;5(1):13-24. https://doi. org/10.1002/ppp.3430050103

20. Hoelzle M, Vonder Mühll D, Haeberli W. Thirty years of permafrost research in the Corvatsch-Furtschellas area, Eastern Swiss Alps: a review. Norsk Geogr Tidsskr Norw J Geogr. 2002;56(2):137-145. https://doi.org/10.1080/002919502760056468

21. Arenson LU. Unstable Alpine Permafrost: A Potential Important Natural Hazard - Variations of Geotechnical Behaviour with Time and Temperature (Ph.D. thesis). Zurich Switzerland: ETH Zurich; 2002. ETH Diss. No. 14801.

22. Vonder Mühll DS. Evidence of intrapermafrost groundwater flow beneath an active rock glacier in the Swiss Alps. Permafrost Periglac Process. 1992;3(2):169-173. https://doi.org/10.1002/ppp.3430030216

23. Frehner M, Ling AHM, Gärtner-Roer I. Furrow-and-ridge morphology on rockglaciers explained by gravity-driven buckle folding: A case study from the Murtèl Rockglacier (Switzerland). Permafrost Periglac Process. 2015;26(1):57-66. https://doi.org/10.1002/ppp.1831

24. Scherler M, Schneider S, Hoelzle M, Hauck C. A two-sided approach to estimate heat transfer processes within the active layer of the MurtèlCorvatsch rock glacier. Earth Surf Dynam. 2014;2(1):141-154. https:// doi.org/10.5194/esurf-2-141-2014

25. PERMOS. Permos borehole data browser. http://shinypermos. geo uzh. ch/app/BoreholeDataBrowser/; 2016. Accessed February 7, 2017.

26. Vonder Mühll D, Haeberli W. Thermal characteristics of the permafrost within an axtive rock glacier (Murtèl/Corvatsch, Grisons, Swiss Alps). J Glaciology. 1990;36(123):151-158. https://doi.org/10.3189/ S0022143000009382

27. Sharma PV. Environmental and Engineering Geophysics. Cambridge, UK: Cambridge University Press; 2002.

28. Schärli U, Rybach L. Determination of specific heat capacity on rock fragments. Geothermics. 2001;30(1):93-110. https://doi.org/10.1016/ S0375-6505(00)00035-3

29. Gieck R. Technische Formelsammlung. 29. Auflage. Germering, Germany: Gieck Verlag; 1989.

30. Zenklusen Mutter E, Phillips M. Thermal evidence of recent talik formation in Ritigraben rock glacier: Swiss Alps. In: Tenth International Conference on Permafrost; 2012:479-483.

31. Herz T, King L, Gubler H. Microclimate within coarse debris of talus slopes in the alpine periglacial belt and its effect on permafrost. In: Proceedings of the Eighth International Conference on Permafrost, Zurich, Switzerland, July; 2003:21, 383-25, 387.

32. Kenner R, Phillips M, Limpach P, Beutel J, Hiller M. Monitoring mass movements using georeferenced time-lapse photography: Ritigraben rock glacier, western Swiss Alps. Cold Reg Sci Technol. 2018;145:127-134. https://doi. org/10.1016/j.coldregions.2017.10.018

33. Kenner R, Phillips M, Beutel J, et al. Factors controlling velocity variations at short-term, seasonal and multiyear time scales, Ritigraben rock glacier, western Swiss Alps. Permafrost Periglac Process. 2017;28(4):675-684. https://doi.org/10.1002/ppp.1953

34. Vonder Mühll D, Haeberli W, Wagner S. Bericht über die Bohrungen und Borlochmessungen im Permafrostbereich der Lawinenverbauungszone. 1991;80:2.
35. Stull RB. An Introduction to Boundary Layer Meteorology. Dordrecht, the Netherlands: Kluwer Academic Publishers; 1988. DOI: https:// doi.org/10.1007/978-94-009-3027-8.

36. Monin A, Obukhov A. Basic laws of turbulent mixing in the surface layer of the atmosphere. Tr Akad Nauk SSSR Geophiz Inst. 1954;24:163-187.

37. Michlmayr G, Lehning M, Koboltschnig G, et al. Application of the Alpine 3D model for glacier mass balance and glacier runoff studies at goldbergkees. Austria Hydrol Process. 2008;22(19):3941-3949. https://doi.org/10.1002/hyp.7102;DOI:10.1002/hyp.7102

38. Clifton A, Manes C, Rüedi JD, Guala M, Lehning M. On shear-driven ventilation of snow. BoundaryLayer Meteorol. 2008;126(2):249-261.

39. Garratt JR, Hicks BB. Momentum, heat and water vapour transfer to and from natural and artificial surfaces. QJ Royal Met Soc. 1973;99(422):680-687. https://doi.org/10.1002/qj.49709942209

40. Staub B, Delaloye R. Using near-surface ground temperature data to derive snow insulation and melt indices for mountain permafrost applications. Permafrost Periglac Process. 2017;28(1):237-248. https://doi. org/10.1002/ppp.1890

41. Gruber S, Hoelzle M. The cooling effect of coarse blocks revisited: a modeling study of a purely conductive mechanism. In: 9th International Conference on Permafrost 2008;557-561. DOI: https://doi.org/ 10.5167/uzh-2823

42. Haberkorn A, Wever N, Hoelzle $M$, et al. Distributed snow and rock temperature modelling in steep rock walls using Alpine3D. Cryosphere. 2017;11(1):585-607. https://doi.org/10.5194/tc-11-585-2017

43. Keller F, Gubler HU. Interaction between snow cover and high mountain permafrost, Murtèl-Corvatsch, Swiss Alps. In: Guodong C, ed. 6th International Conference on Permafrost. Proceedings. Beijng, China: South China University of Technology Press; 1993:332-337.

44. Keller F, Tamás M. Enhanced ground cooling in periods with thin snow cover in the Swiss national park. In: Phillips M, Springman SM, Arenson LU, eds. Proceedings of the Eighth International Conference on Permafrost, Zurich, Switzerland, July 21-25; 2003:531-536.

45. Zhang T. Influence of the seasonal snow cover on the ground thermal regime: an overview. Rev Geophys. 2005;43(4). https://doi.org/ 10.1029/2004RG000157

46. Wagenbach D. Tritium. In: Haeberli W, ed. Pilot Analyses of Permafrost Cores from the Active Rock Glacier Murtèl I, Piz Corvatsch, Eastern Swiss Alps; 1990:29-30.

47. Stauffer B, Wagenbach D. Stable isotopes. In: Haeberli W, ed. Pilot Analyses of Permafrost Cores from the Active Rock Glacier Murtèl I, Piz Corvatsch; 1990:22-23.

How to cite this article: Pruessner L, Phillips M, Farinotti D, Hoelzle M, Lehning M. Near-surface ventilation as a key for modeling the thermal regime of coarse blocky rock glaciers. Permafrost and Periglac Process. 2018;29:152-163. https:// doi.org/10.1002/ppp.1978 